\title{
Cerebrospinal fluid protein fractions in health and disease
}

\author{
C. J. BRACKENRIDGE ${ }^{1}$ \\ From the Biochemistry Department, Royal Perth Hospital, Perth, \\ Western Australia
}

SYNOPSIS Samples of lumbar cerebrospinal fluid from 20 healthy subjects and 20 patients with $\dot{\varepsilon r}$ variety of neurological disorders have been subjected to cellulose acetate electrophoresis andwo quantitative analyses carried out on the seven separated protein fractions. Normal percentage and absolute concentration limits for each fraction have been determined and compared with previouso reports. It is concluded that absolute values are more valuable than percentage values in the discrimination of disease from health, but that the mechanisms governing protein abnormalities arez difficult to ascertain from spinal fluid electrophoresis alone.

The value of electrophoretic analysis of the serum proteins as a diagnostic aid has led to its application to the study of the cerebrospinal fluid proteins. Hesselvik (1939) first extended the use of the Tiselius moving boundary method to the separation of spinal fluid proteins but the large volumes required and the attendant technical difficulties militated against its general adoption. Schneider and Wallenius (1951) pioneered the paper electrophoretic study of the proteins and with the development of new membranes more sensitive techniques were devised. Thus Pette (1958) characterized nine fractions on agar gel compared with the usual five on paper. Immunoelectrophoresis, by virtue of its sensitivity and specificity, promises to be a fruitful method for future investigations (Gavrilesco, Courcon, Hillion, Uriel, Lewin, and Grabar, 1955).

A review of the literature shows that, while several quantitative analyses of spinal fluid proteins in health and disease have been performed by paper electrophoresis (Lemmen, Newman, and DeJong, 1957), practically all studies using improved membranes have only been of a qualitative nature. Further, even with paper electrophoresis, normal ranges of protein fractions have been established in very few cases: there has thus been a paucity of normal values with which to compare data from disease states. The advantages of cellulose acetate as an electrophoretic medium are now well docu-

Received for publication 2 October 1961.

${ }^{1}$ Present address: Department of Biochemistry, College of Medicine, University of Florida, Gainesville, Florida, U.S.A. mented (Kohn, 1958a, b; Smith and Murchison, 1959). It therefore seemed worth while to investigate the concentrations and distributions of protein fractions in the cerebrospinal fluid by means of the cellulose acetate electrophoretic method previouslya devised for the serum proteins (Brackenridge, 1960a $\overrightarrow{\overrightarrow{0}}$ b, c).

The present report is a preliminary and exploratory study, the twofold purpose of which is to determine the concentration limits of the spinal fluid proteing fractions in health and to note any abnormalities found in some typical cases of neurological disorders with a view to more extensive subsequent study if indicated.

\section{MATERIAL AND METHODS}

All samples of cerebrospinal fluid were obtained by lumbar puncture. Subjects who underwent lumbar o puncture to exclude neurological illness and were lateŕ regarded as clinically normal at that time in the light of their case histories were included in a normal controtw group. The abnormal group consisted of hospital patientso clinically diagnosed to be suffering from neurologicalo disease at the time of lumbar puncture. Although caseswere selected at random, the material was reasonablyes broad and diverse in scope.

Estimation of the total protein content was performed on $0.5 \mathrm{ml}$. of fluid by a modification of the method of Yeoman (1955); close agreement between such salicyl $\frac{\rho}{?}$ sulphonic acid turbidimetric procedures and micro $\mathbb{2}$ Kjeldahl analyses has been demonstrated (Wikoff ando Kazdan, 1951).

Fluid was concentrated by dialysis in cellophane bag 
against a $10 \%$ aqueous solution of gum acacia for periods of one to three days. When at least a tenfold concentration had been attained, the fluid was subjected to electrophoresis precisely as reported for serum (Brackenridge, 1960 b) except that up to 10 times the quantity was applied when the total protein content was low.

Seven distinct fractions (pre-albumin, albumin, $\alpha_{1-}$, $\alpha_{2^{-}}, \beta_{1^{-}}, \beta_{2^{-}}$, and $\gamma$-globulins) could be consistently differentiated on cellulose acetate (Colover, 1961). After staining, the dye bound to each fraction was eluted, the dye-binding capacities being assumed identical to those of the corresponding serum protein fractions (Brackenridge, 1960a). The dye-binding capacity of the most mobile fraction, pre-albumin, which is virtually absent from serum, was determined by staining known amounts of a commercially pure product ${ }^{1}$ under identical experimental conditions.

Concentrations of fractions were expressed both relatively as percentages of the total, and absolutely as milligrams per $100 \mathrm{ml}$. of original fluid. It is assumed that protein characteristics were not altered during dialysis and electrophoresis. This appears valid since no denaturation was observed during electrophoresis judging by the absence of accumulated material at the starting point. On the other hand Gries, Aly, and von Oldershausen (1953) in an evaluation of concentration techniques found ultrafiltration with protein-impermeable membranes to have the least influence on the cerebrospinal fluid proteins.

Behringwerke, Marburg Lahn, Germany.

\section{RESULTS}

NORMAL VALUES The percentage and absolute concentrations of spinal fluid proteins in the healthy control group, comprising 14 males and six females, are shown in Table $\mathbf{I}$. In addition to the mean values, the lower and upper limits of the normal range, defined as the range embracing $95 \%$ of the normal population, are tabulated for pre-albumin, albumin, the five globulins, and the total proteins. The limits are calculated as \pm 2 standard deviations from the mean of the distribution.

The small but significant differences between the total protein concentration and the sum of the constituent concentrations arise from the various frequency distributions of the fractions. While the total protein concentrations of the group are approximately normally distributed, the majority of those of the fractions are lognormally distributed, hence the total figure is somewhat in excess of the sum of the components.

It has been clearly demonstrated that the spinal fluid protein concentrations must be considered in relation to the age of the subject. Newborn infants have a high content due presumably to a poorly developed blood-brain barrier (Levinson, 1950), while a similar tendency is observed over the age of

TABLE I

NORMAL SPINAL FLUID PROTEIN VALUES ${ }^{1}$

\begin{tabular}{|c|c|c|c|c|c|c|c|c|}
\hline & $\begin{array}{l}\text { Pre- } \\
\text { albumin }\end{array}$ & Albumin & $a_{1}$ & $a_{2}$ & $\beta_{1}$ & $\beta_{2}$ & $\gamma$ & $\begin{array}{l}\text { Total } \\
\text { Proteins }\end{array}$ \\
\hline $\begin{array}{l}\text { Mean percentage concentration } \\
\text { Lower limit } \\
\text { Upper limit } \\
\text { Distribution }{ }^{2}\end{array}$ & $\begin{array}{r}7 \cdot 0 \\
4 \cdot 2 \\
10 \cdot 2 \\
\text { L }\end{array}$ & $\begin{array}{c}49 \cdot 0 \\
40 \cdot 9 \\
58 \cdot 6 \\
L\end{array}$ & $\begin{array}{r}7 \cdot 0 \\
2 \cdot 8 \\
9 \cdot 0 \\
\mathbf{A}\end{array}$ & $\begin{array}{c}8 \cdot 6 \\
4 \cdot 8 \\
12 \cdot 4 \\
N\end{array}$ & $\begin{array}{r}12 \cdot 0 \\
9 \cdot 2 \\
14 \cdot 8 \\
N\end{array}$ & $\begin{array}{r}6 \cdot 9 \\
4 \cdot 7 \\
10 \cdot 2 \\
\text { L }\end{array}$ & $\begin{array}{r}9 \cdot 3 \\
5 \cdot 5 \\
13 \cdot 1 \\
N\end{array}$ & \\
\hline $\begin{array}{l}\text { Mean absolute concentration } \\
\text { Lower limit } \\
\text { Upper limit } \\
\text { Distribution }{ }^{2}\end{array}$ & $\begin{array}{l}1 \cdot 9 \\
1 \cdot 0 \\
3 \cdot 3 \\
L\end{array}$ & $\begin{array}{r}13 \cdot 1 \\
7 \cdot 3 \\
23 \cdot 5 \\
\mathrm{~L}\end{array}$ & $\begin{array}{l}1 \cdot 7 \\
1 \cdot 0 \\
3 \cdot 1 \\
L\end{array}$ & $\begin{array}{l}2 \cdot 2 \\
1 \cdot 2 \\
4 \cdot 3 \\
L\end{array}$ & $\begin{array}{l}3 \cdot 2 \\
1 \cdot 7 \\
5 \cdot 8 \\
\mathrm{~L}\end{array}$ & $\begin{array}{l}1.9 \\
0.9 \\
3.8 \\
\text { L }\end{array}$ & $\begin{array}{l}2 \cdot 5 \\
0 \cdot 9 \\
4 \cdot 1 \\
\mathrm{~N}\end{array}$ & $\begin{array}{l}27 \\
13 \\
41 \\
N\end{array}$ \\
\hline
\end{tabular}

${ }^{1}$ Absolute concentrations expressed as $\mathrm{mg}$. per $100 \mathrm{ml}$. fluid.

${ }^{2} \mathbf{A}=$ Antilognormal, $\mathbf{L}=$ Lognormal, $\mathbf{N}=$ Normal.

TABLE II

COMPARISON OF NORMAL CEREBROSPINAL FLUID PROTEIN VALUES, EXPRESSED AS MEAN PERCENTAGE, WITH PUBLISHED RESULTS

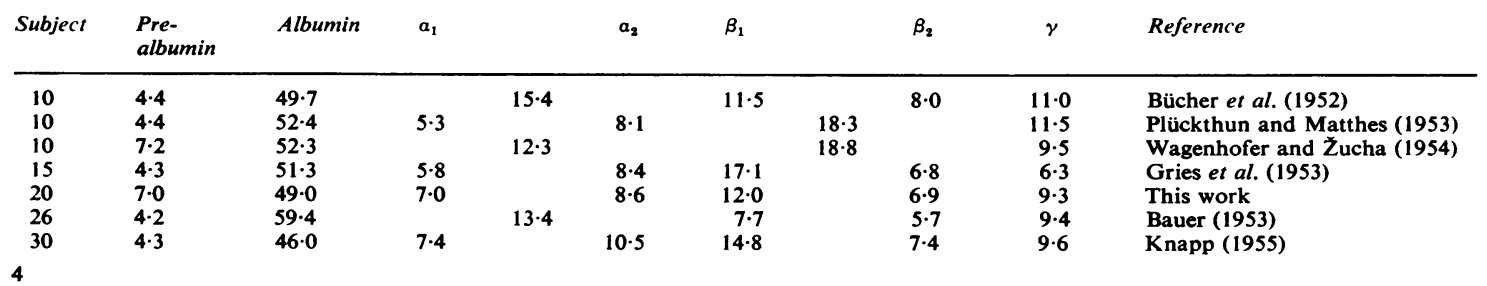


60 (Madonick and Weissman, 1955). In the present study the ages of the subjects ranged from 13 to 66 . They were lognormally distributed, the mean being 33 and the range of \pm 1 standard deviation being 20 to 53 .

In Table II mean percentage concentrations of fractions are compared with other published values obtained with paper electrophoresis.

PATHOLOGICAL VALUES The relative and absolute concentrations of lumbar fluid proteins in the group with specified diagnoses are shown in Table III. The male to female ratio is appreciably lower than in the normal group. The mean age \pm 1 standard deviation was $44 \pm 22$ when calculated from a normally distributed group. This difference from the control data is not statistically significant.

\section{DISCUSSION}

NORMAL VALUES In comparing the normal values $\stackrel{\overrightarrow{\vec{S}}}{\rightarrow}$ obtained in the present study with those publishedo elsewhere (Tables I and II), it is important to recognize the factors which affect the protein content. $\frac{\bar{\rho}}{2}$ These are the age (but not the sex) of the subject, the $\stackrel{\mathbb{\Phi}}{\Omega}$ site of puncture, and the assumptions underlying the method (such as identical dye uptake or nitrogen factor of fractions). Of lesser importance is the. technique of cerebrospinal fluid concentration. $\vec{\omega}$ Taking these variables into account, the valueso quoted in Table II are in reasonable agreement with those determined by cellulose acetate electrophoresis and with each other. With regard to the absolute ${ }_{\omega}^{G}$ concentrations (Table $\mathrm{I}$ ), it is surprising that, to theiv author's knowledge, no normal values have pre-চ viously been reported.

TABLE III

PERCENTAGE AND ABSOLUTE SPINAL FLUID PROTEIN CONCENTRATIONS IN DISEASE ${ }^{1}$

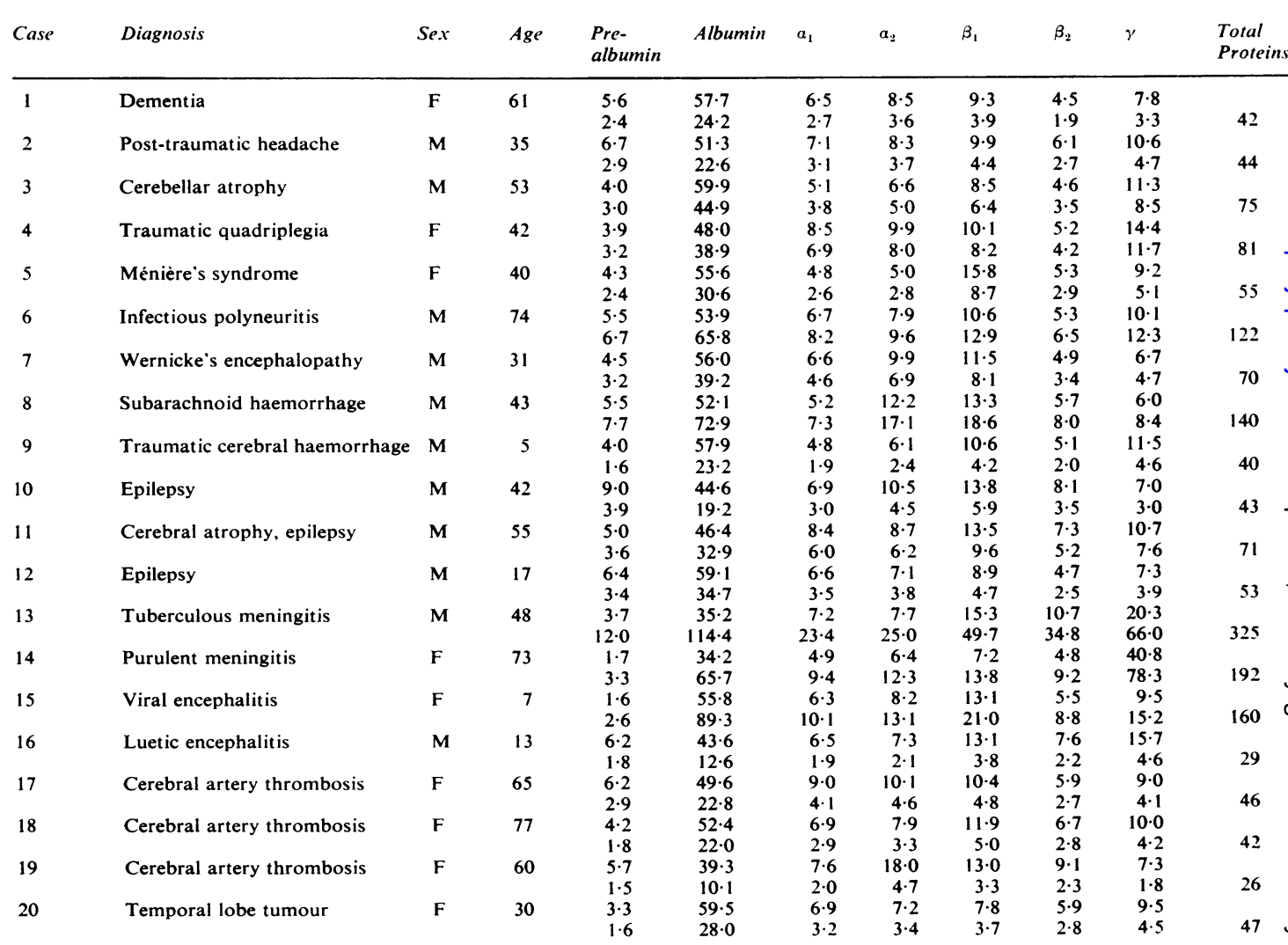

${ }^{1}$ Absolute values expressed as $\mathrm{mg}$. per $100 \mathrm{ml}$. fluid. 
Table IV, based on the serum pre-albumin figure of Schultze and Schwick (1959) and the serum protein values of Brackenridge (1960d), indicates that the most obvious features of cerebrospinal fluid compared with blood serum are the low total protein content and the high percentage concentration of pre-albumin. Such biochemical differences are compatible with the idea of a blood-brain barrier. Admixture with blood will be expected to lower the percentage lumbar fluid pre-albumin concentration, slightly raise the albumin, lower the $a_{1}$-globulin, raise the $\alpha_{2}$-globulin, lower both $\beta$-globulins, and raise the $\gamma$-globulin. There will be a concomitant absolute raising of the total protein content.

PATHOlOgical VAlues Since a major purpose of this study is to test the value of quantitative analysis of spinal fluid proteins in the diagnosis of neurological disease, only the pathological cases as a whole will be discussed to see whether the results of this group differ appreciably from normal values. It is evident that little significance can be attached to any variations from the normal limits encountered in a few isolated cases of a particular disease. A convenient summary of the data in Table III is presented in Table $\mathrm{V}$. The conclusions to be drawn from an inspection of the results may be briefly described as follows.

Individual inspection of the pathological data (Table III) shows that at least one abnormal value, relative or absolute, occurs in every case. More precisely, there is at least one abnormal absolute value in all 20 cases whereas there is at least one abnormal relative value in 12 cases.

Absolute concentrations are a much more sensitive index of a disease process than percentage concen- trations: the number of abnormal absolute concentrations in the group totals 76 (excluding total proteins), but the number of abnormal relative concentrations is only 27 .

The fractions of which the percentage concentrations are most affected by disease are pre-albumin (in $35 \%$ of cases) followed by albumin and $\beta_{1}$ globulin (both in $30 \%$ of cases). While the prealbumin level is always decreased, the levels of albumin and $\beta_{1}$-globulin are decreased and increased about equally.

The fractions of which the absolute concentrations are most affected by disease are the total protein (in $85 \%$ of cases) followed by $\gamma$-globulin (in $75 \%$ of cases) and albumin (in $65 \%$ of cases). The alterations are always increases.

It is clear from these findings that, with the single possible exception of pre-albumin (Table V), absolute levels calculated from the total protein content are of more value than relative figures. The most extreme example is seen in the $a_{1}$-globulin fraction which always revealed a normal percentage level whereas the absolute level was raised in 12 of the 20 patients. Cases 6,7 , and 8 (Table III) further prove this point: with total protein values as high as 55,122 , and 70 , the percentage concentrations of all fractions in each case were normal. This emphasizes the serious deficiency in the literature where only percentage concentrations appear to have been reported for various disorders and in health. In comparing the relative and absolute concentrations of individual fractions in disease (Table V), the most interesting are pre-albumin (in which the percentage level is always lowered and the absolute level is never raised) and $\gamma$-globulin (in which both levels are always raised).

TABLE IV

COMPARISON OF NORMAL MEAN PERCENTAGE PROTEIN CONCENTRATIONS IN SPINAL FLUID AND BLOOD SERUM

\begin{tabular}{lcccccc} 
& Pre-albumin & Albumin & $a_{1}$ & $\alpha_{2}$ & $\beta$ & $\gamma$ \\
\hline Spinal fluid & 7.0 & $49 \cdot 0$ & 7.0 & 8.6 & 18.9 & $9 \cdot 3$ \\
Blood serum & 0.3 & $55 \cdot 3$ & $4 \cdot 1$ & $10 \cdot 6$ & 12.5 & 17.5 \\
Serum: fluid ratio & 0.04 & 1.13 & 0.59 & 1.23 & 0.66 & 1.88
\end{tabular}

TABLE V

NUMBER OF ABNORMAL VALUES, EXPRESSED AS INCREASED (I) OR DECREASED (D), IN PROTEIN FRACTIONS OF 20 SPINAL FLUIDS IN DISEASE

\begin{tabular}{|c|c|c|c|c|c|c|c|c|c|c|c|c|c|c|c|c|}
\hline \multirow[t]{2}{*}{ Concentration } & \multicolumn{2}{|c|}{ Pre-albumin } & \multicolumn{2}{|c|}{ Albumin } & \multicolumn{2}{|l|}{$a_{1}$} & \multicolumn{2}{|l|}{$a_{9}$} & \multicolumn{2}{|l|}{$\beta_{1}$} & \multicolumn{2}{|l|}{$\beta_{\mathbf{q}}$} & \multicolumn{2}{|l|}{$\gamma$} & \multicolumn{2}{|c|}{ Total Protein } \\
\hline & $I$ & $D$ & $I$ & $D$ & $I$ & $D$ & $I$ & $D$ & $I$ & $D$ & $I$ & $D$ & $I$ & $D$ & $I$ & $D$ \\
\hline
\end{tabular}


The operation of possible pathological mechanisms such as increased permeability of the bloodbrain barrier, abnormal secretion of fluid through the choroid plexuses, and protein release by necrosis of nervous tissue cannot be assessed in the present study. It is likely that a larger selection of material supplemented by the differential serum protein values will elucidate some of the underlying aberrant mechanisms responsible for the abnormal lumbar fluid results.

\section{REFERENCES}

Bauer, H. (1953). Dtsch. Z. Nervenheilk., 170, 381

Brackenridge, C. J. (1960a). Analyt. Chem., 32, 1353.

(1960b). Ibid., 32, 1357.

(1960c). Ibid., 32, 1359

(1960d). Nature (Lond.), 188, 155.

Bücher, T., Matzelt, D., and Pette, D. (1952). Klin. Wschr., 30, 325.
Colover, J. (1961). Biochem. J., 78, 5P.

Gavrilesco, K., Courcon, J., Hillion, P., Uriel, J., Lewin, J., and Grabar, P. (1955). Nature (Lond.), 176, 976.

Gries, G., Aly, F. W., and Oldershausen, H. F. von (1953). Klin. Wschr, 31, 644 .

Hesselvik, L. (1939). Acta med. scand., 101, 461.

Knapp, A. (1955). Arch. klin. exp. Derm., 201, 446.

Kohn, J. (1958a). Nature (Lond.), 181, 839.

- (1958b). Clin. chim. Acta, 3, 450.

Lemmen, L. J., Newman, N. A., and DeJong, R. N. (1957). Univ. \ి Mich. med. Bull., 23, 3.

Levinson, A. (1950). Med. Clin. N. Amer., 34, 107.

Madonick, M. J., and Weissman, F. (1955). Geriatrics, 10, 533.

Pette, D. (1958). Klin. Wschr., 36, 1106.

Plückthun, H., and Matthes, A. (1953). Z. Kinderheilk., 72, 521.

Schneider, G., and Wallenius, G. (1951). Scand. J. clin. Lab. Invest., 3,145 .

Schultze, H. E., and Schwick, G. (1959). Clin. chim. Acta, 4, 15

Smith, D. C., and Murchison, W. (1959). J. med. Lab. Technol., 16. 197.

Wagenhofer, E., and Žucha, J. (1954). Bratisl. lek. Listy., 34, 713.

Wikoff, H. L., and Kazdan, P. (1951). Amer J clin. Path, 21, 1173 C

Yeoman, W. B. (1955). J. clin. Path., 8, 252. 